\title{
Uses of EAFS in production of blended cements
}

\author{
Asmaa Sarhan ${ }^{a, *}$, Essam A. Kishar ${ }^{b}$, Samya A. Hamed ${ }^{a}$ \\ ${ }^{a}$ National Institute of Safety and Health, Cairo, Egypt. \\ ${ }^{b}$ Chemistry Department, Faculty of women for Arts, Science and Education, Ain Shams University, \\ Cairo, Egypt.
}

\begin{abstract}
In this investigation the goal is to prepare different blended cements by blending various mixes using electric arc furnace slag EAFS (90\%OPC+10\%EAFS) mixes, $(80 \% \mathrm{OPC}+20 \% \mathrm{EAFS})$ and $(70 \% \mathrm{OPC}+30 \% \mathrm{EAFS})$.These materials are combined with different $\mathrm{w} / \mathrm{s}$ ratios then poured into 1 inch cubic moulds and left within the moulds at room temperature $\left(25 \pm 1^{\circ} \mathrm{C}\right)$ and $100 \%$ relative humidity for 1day.They are then taken out of moulds and cured under tap water for 3,7,28,90 and 180 days. For each hydration time, combined water, compressive strength, total porosity and bulk density. The X-ray diffraction patterns are then registered. The results show that the blends containing $(90 \% \mathrm{OPC}+10 \% \mathrm{EAFS})$ and $(80 \% \mathrm{OPC}+20 \% \mathrm{EAFS})$ are the best blended pastes.
\end{abstract}

Keywords: OPC, EAFS, Blended cement, XRD.

\section{Introduction}

Cement is a finely grey powder. Which is used and mixed with water to form a hardening paste of calcium aluminate hydrates $(\mathrm{CAH})$ and calcium silicate hydrates $(\mathrm{CSH})$. Cement is used in concrete by mixing with sand, aggregate and water. Also cement is used in mortar by binding together with stones or brick. By changing the raw material mix and the temperature used in its production, compositional changes occured that lead to production of cements with different properties. Cement is composed from raw materials such as limestone, chalk, shale, clay, and sand. These contents are whisked, cracked and mixed to the correct chemical composition. Small amounts of additives such as alumina sources, iron ore and other mineral supplies may be added to complete the contents. A large kiln is needed for feeding raw materials, which form a hard material product called "clinker" as a result of the extremely high temperature that reach almost to $1450^{\circ} \mathrm{C}$. . About 5 percent gypsum is added to the Clinker after being grounded and other minor additives to produce Portland cement after being cooled.

*Corresponding author: Asmaa Sarhan, National Institute of Safety and Health, Cairo, Egypt .

E-mail: asmaagohar29@yahoo.com 
TheCement industry is one of the main industries that emit $\mathrm{CO}_{2}$ in high quantities as a result of the fuel combustion besides the de-carbonation of limestone. About $900 \mathrm{~kg}$ of $\mathrm{CO}_{2}$ are emitted for every $1000 \mathrm{~kg}$ of cement produced, $\mathrm{CO}_{2}$ emissions cause bad weather conditions, ecosystems damage and climate change, besides the emission of SOx, NOx and particulate matter that harm the health of humans and livestocks [5]. As a result, the use of cementitious materials such as industrial wastes and pozzalana (siliceous/aluminous materials) is increased for replacing partially Portland cement and forming blended cement [1].

\section{Blended cement}

Blended cements are produced by partial replacement of OPC with one or more SCMs (supplementary cementing materials) such as pozzalana which improves long-term strength and durability. reduces quantity of landfilled wastes and reduces the quantity of clinker required. SCM is one of the most sustainable produced substances as it recovers a commercial byproduct through beneficial use when incorporated into concrete it also avoids disposal of industrial byproducts, increases structure service life by improving the durability of concrete and reduces Portland cement content in concrete, that reduces the use of natural raw materials and hence reduce emissions of greenhouse gas [6].

\section{Pozzalana}

According to ACI, pozzalana is a siliceous or a siliceous and aluminous material that in itself possesses little or no cementicious value, but in presence of moisture it chemically reacts with calcium hydroxide (lime) or any other alkalis at ordinary temperature to form compounds having high cementicious properities. To obtain strength a highly reactive pozzalan has more cementicious strength value than a lower reactive pozzalan. The quantity of cement reduction would be greater with a more reactive pozzolan, artificial and natural pozzolana are two types of Pozzolanic materials,.

(1) Natural pozzolans are natural products such as (volcanic ash, volcanic tuff) and agricultural products as rice-husk ash and wood ash.

(2) Artificial pozzolans are almost industrial by-products. They consist of burnt clay and some industrial wastes (e.g. slag, silica fume and cement kiln dust) even fly ash produced by coal burning plants; incineration of municipal solid wastes and other treated calcined materials, such as rice husk ashes ,burned clay shales (metakaoline) 
waste glasses and burned organic matter. These industrial wastes contain major constituents as $\mathrm{SiO}_{2}, \mathrm{Al}_{2} \mathrm{O}_{3}, \mathrm{Fe}_{2} \mathrm{O}_{3}, \mathrm{CaO}, \mathrm{MgO}$ and other minor oxides.

\section{Pozzolanic reaction:}

Pozzalanic reaction takes place when quantities of reactive $\mathrm{SiO}_{2}, \mathrm{Al}_{2} \mathrm{O}_{3}$ and $\mathrm{CaO}$ are mixed with water, $\mathrm{CaO}$ is added as Lime or cement, which in the hydration process liberates $\mathrm{OH}^{-}$ions, consequently increases $\mathrm{pH}$ value up to 12.4 that enhances, the pozzolanic reaction, $\mathrm{Si}$ and $\mathrm{Al}$ combine with $\mathrm{Ca}$ forming Calcium Silicate Hydrate $(\mathrm{CSH})$ and Calcium Aluminate Hydrate (CAH) [3], [7], [8], [4],[2].

$$
\begin{aligned}
& \mathrm{Ca}(\mathrm{OH})_{2} \longrightarrow \mathrm{Ca}^{+2}+2 \mathrm{OH}^{-} \\
& \mathrm{Ca}^{+2}+2 \mathrm{OH}^{-}+\mathrm{SiO}_{2} \longrightarrow \mathrm{CSH} \\
& \mathrm{Ca}^{+2}+2 \mathrm{OH}^{-}+\mathrm{Al}_{2} \mathrm{O}_{3} \longrightarrow \mathrm{CAH}
\end{aligned}
$$

\section{Experimental Work}

The materials used in this study are, electric arc furnace slag (EAFS) and ordinary Portland cement(OPC). The chemical composition of the starting materials are given in Table (1) Different mixes are prepared by mixing the constituents with different ratios as shown in Table (2). 
Table (1): The chemical composition of the starting materials

\begin{tabular}{|c|c|c|}
\hline MixAbb. & OPC & EAFS \\
\hline $\mathrm{SiO}_{2}$ & 20.18 & 18.3 \\
\hline $\mathrm{Al}_{2} \mathrm{O}_{3}$ & 4.71 & 4.75 \\
\hline $\mathrm{Fe}_{2} \mathrm{O}_{3}$ & 3.90 & 10.90 \\
\hline $\mathrm{CaO}$ & 63.90 & 36.60 \\
\hline $\mathrm{MgO}$ & 1.98 & 11.60 \\
\hline $\mathrm{SO}_{3}$ & 2.98 & 1.250 \\
\hline $\mathrm{K}_{2} \mathrm{O}$ & 0.29 & 0.191 \\
\hline $\mathrm{Na}_{2} \mathrm{O}$ & 0.50 & - \\
\hline $\mathrm{Cl}^{-}$ & 0.29 & 0.204 \\
\hline L.O.I & 0.90 & 13.2 \\
\hline Total & 99.63 & 96.99 \\
\hline
\end{tabular}

Mix Abb. refers to mix abbreviation 
Table (2): composition of the prepared mixes.

\begin{tabular}{|c|c|c|c|}
\hline No. & Mix Abb. & OPC\% & EAFS \% \\
\hline 1 & C & 100 & - \\
\hline 2 & CA1 & 90 & 10 \\
\hline 3 & CA2 & 80 & 20 \\
\hline 4 & CA3 & 70 & 30 \\
\hline
\end{tabular}

Blended cement is obtained by the addition of (EAFS) to (OPC) in the ratios 10, 20 and $30 \%$, as shown in Table (2) then adding the suitable amount of water with different w/s ratios. The paste is placed in the stainless steel mold 1- cubic inch -shaped molds, and immediately placed in humidifier $\left(100 \% \mathrm{R} . \mathrm{H}\right.$.) at room temperature $\left(25 \pm 1^{\circ} \mathrm{C}\right)$ for the first 24 hrs . After this period, the cubes are removed from the mold and cured under tap water until the required time of testing 3,7,28,90, and 180 days.

The hydration characteristics of the different mixes have been tested via determination of compressive strength, combined water, bulk density, total porosity. The formed hydration products are determined by XRD analysis.

After compressive strength measurements a few grams is taken from the crushed cubes and stirred with about $100 \mathrm{ml}$ of $(1: 1 \mathrm{v} / \mathrm{v})$ methyl alcohol and acetone to stop the hydration. After filtration the sample is dried at $100{ }^{\circ} \mathrm{C}$ for $24 \mathrm{hrs}$, and then kept for analysis.

\section{Results and discussions}

\section{A.1. Compressive strength}

The compressive strength of blended-EAF binder cured up to 180 days shown in graphically represented in Figure (1). It is shown that as the curing time proceeds for all the hardened pastes, the compressive strength increases. This may be due to the accumulation of a great quantityof hydration products, which enter the pores to form a more rigid structure. $10 \%, 20 \%$ EAFS gives the highest values of compressive strength of the blended cement EAFS mixes this is due to the acceleration of the activation process caused by slag. 


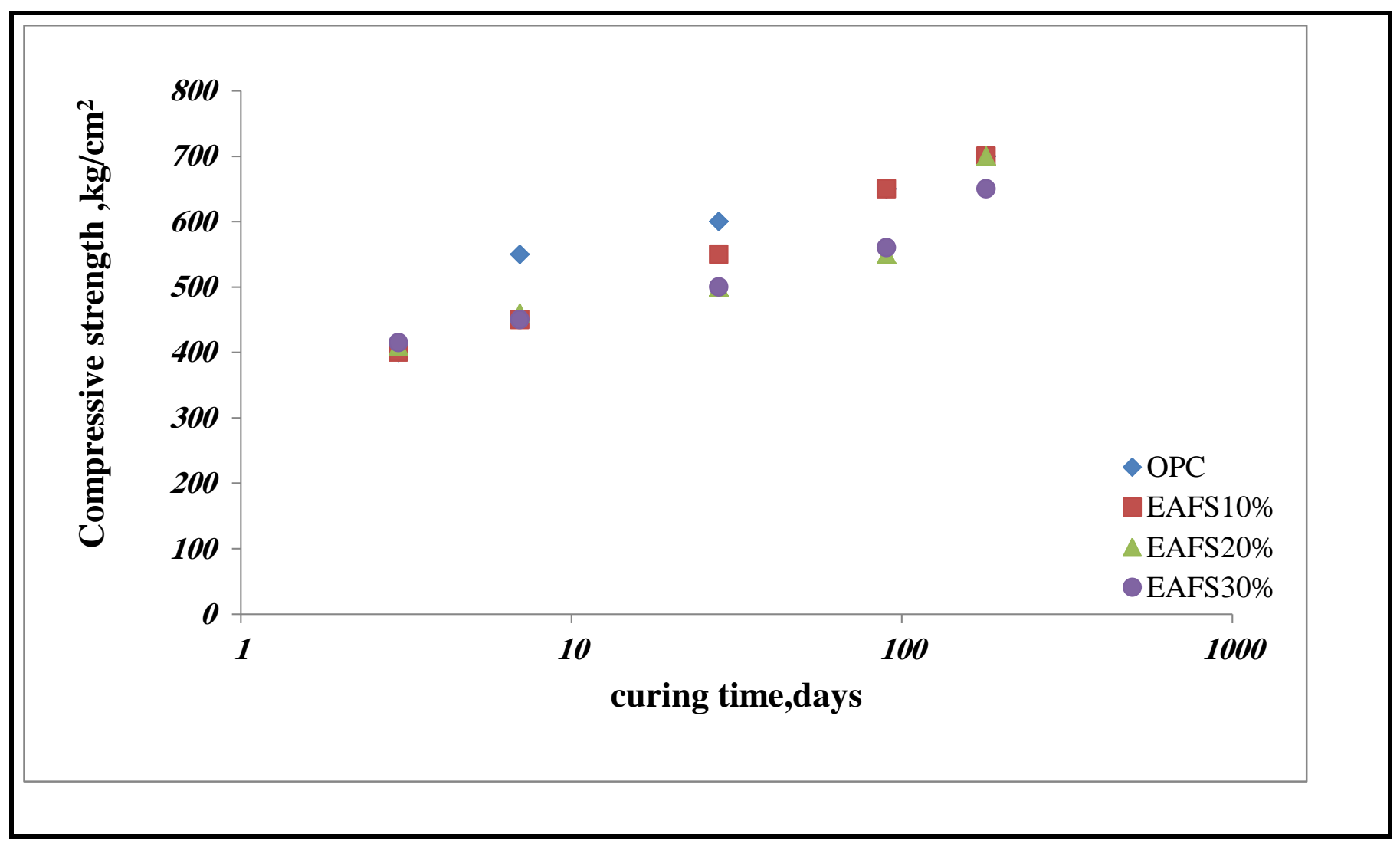

Fig.1 Compressive strength in $\mathrm{kg} \mathrm{cm}^{-2}$ of OPC-EAFS blended mixes cured in $\mathrm{H}_{2} \mathrm{O}$ up to 180 days.

\section{III.A.2. Chemically combined water contents}

The results of chemically combined water contents of the blended OPC -EAFS pastes are represented in Figure (2). The combined water contents depend on the quantiti and kind of the hydration products. As the curing time proceeds for all mixes containing OPC-EAFS the chemically combined water contents increases indicating more hydration products are present and precipitated in the open pores. 


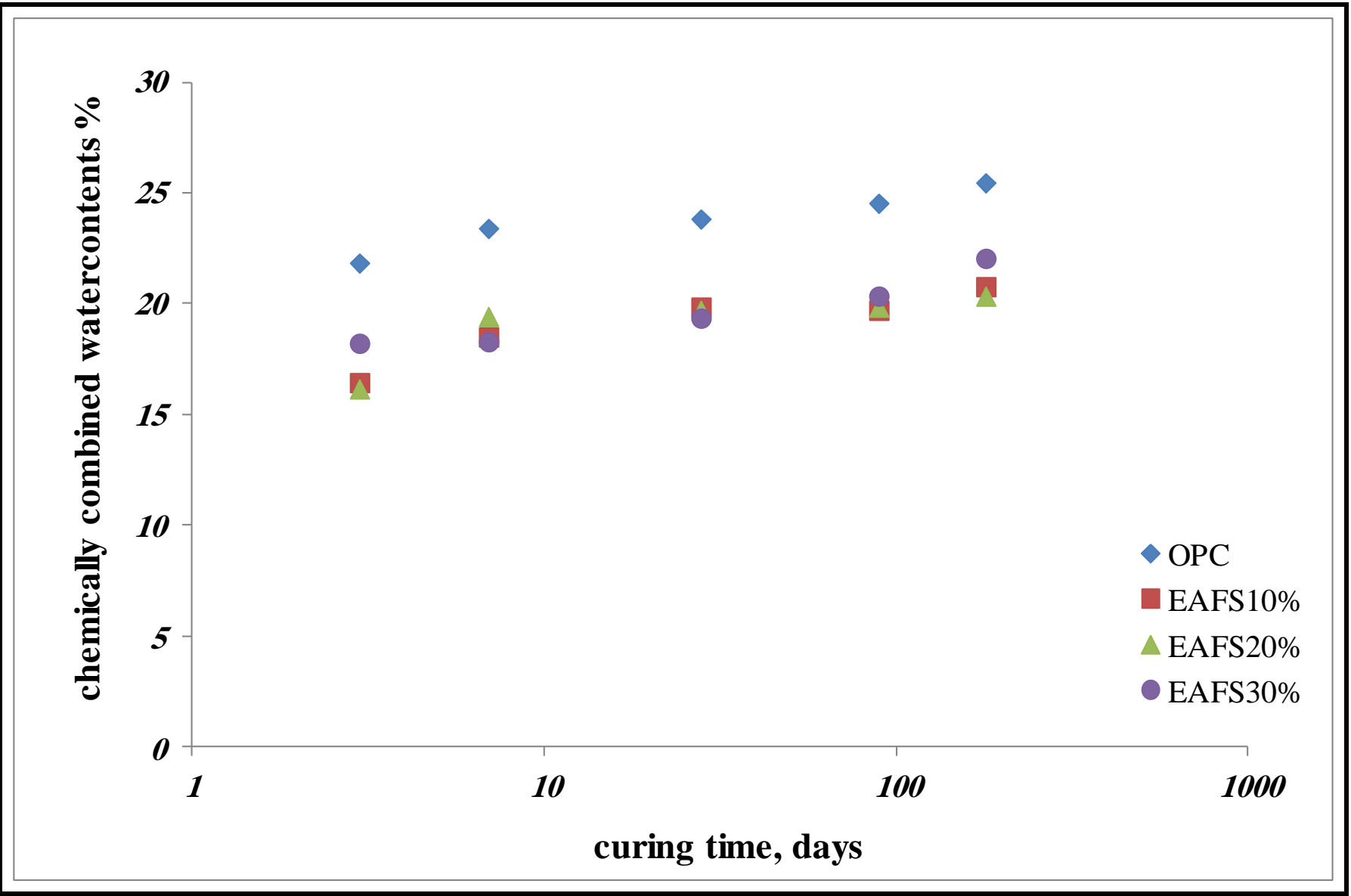

Fig.2 Chemically combined water content in \% of OPC-EAFS blended mixes cured up to 180 days

\section{A.3. Bulk density:}

The determined bulk density of OPC - EAFS pastes treated up to 180 days in water is graphically represented in Figure (3). It is obvious that as the curing time for all mixes develops, the bulk density increases. This means that as the hydration products are perciptated in the open pores as the hydration proceeds, therefore the bulk density increases. 


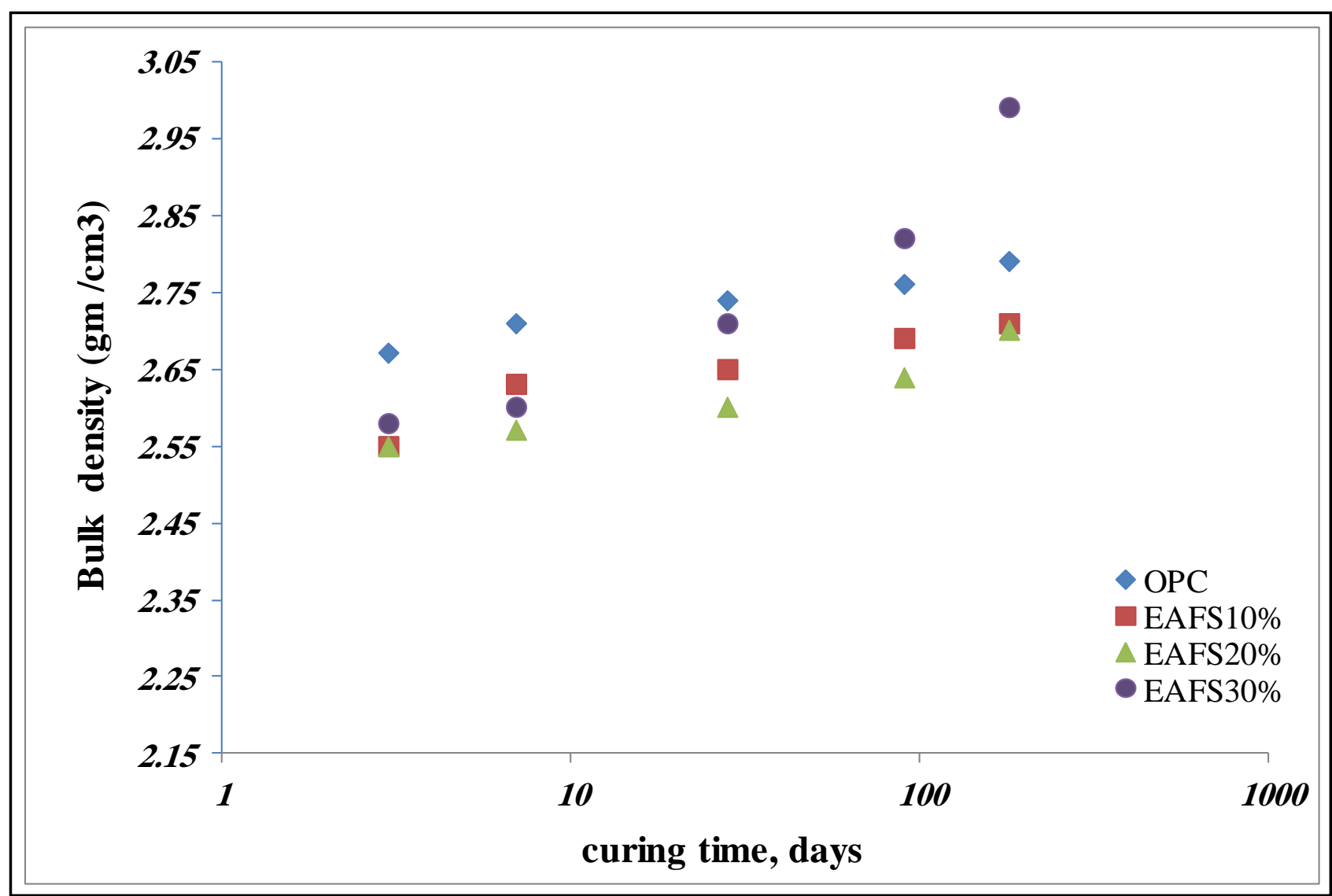

Fig.3 Bulk density in $\mathrm{g} \mathrm{cm}^{-3}$ of OPC-EAFS blended mixes cured up to 180 days.

\section{III.A.4. Total porosity}

The results of total porosity of blended OPC - EAFS pastes treated up to 180 days in water are graphically represented in Figure (4). It is clear that all the values of total porosity decrease with treating time. These result indicate that the hydration products may be precipitated to fill up the pores to minimum values at 180 days. These results agree with those data obtained for the compressive strength and other investigation tests. 


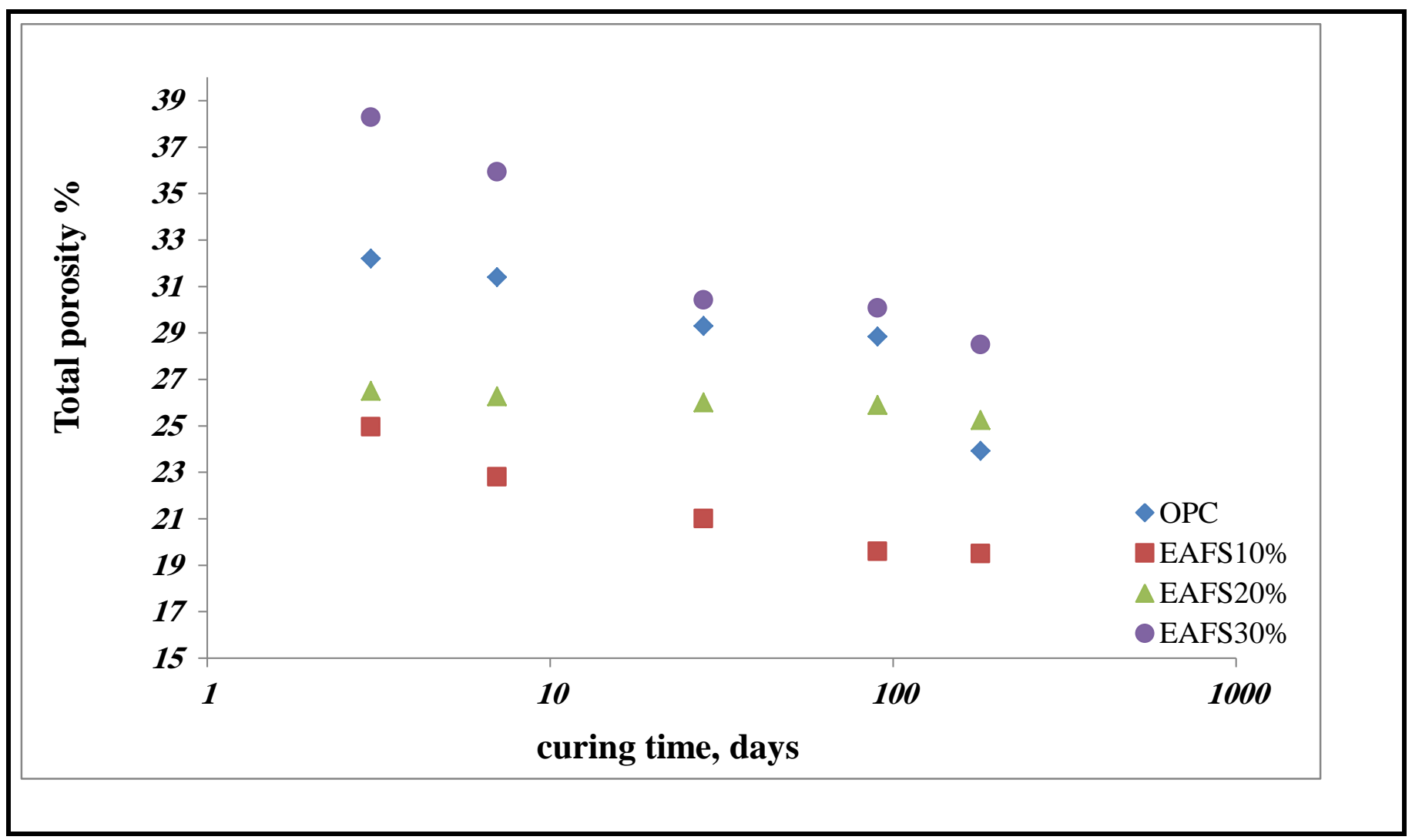

Fig.4 Total porosity in $\%$ of OPC-EAFS blended mixes cured up to 180 days

\section{A.5. X-ray diffraction analysis}

XRD patterns of OPC-EAFS (CA1- CA 2-CA3) are shown in Figs. $(5,6,7)$, the peak can be observed in the range of $29.22-30.81^{\circ}$, which is for CSH is increased in the mix CA2 and CA3 more than that appeared in CA1, $2 \Theta$ changes with curing time up to 90 days, the presence of the strong peaks at $\mathrm{d}=3.05$ and $2.11 \mathrm{~A}^{\mathrm{o}}$ is attributed to CSH phase (okenite), and the presence of other phases such as portlandite $(\mathrm{CH})$ at $\mathrm{d}=4.69,3.13^{\circ}, 2.64 \mathrm{~A}^{\mathrm{o}}$ and quartz $(\mathrm{SiO} 2)$ at $\mathrm{d}=3.41 \mathrm{~A}^{\mathrm{o}}$. The intensity of $\mathrm{CH}$ peaks increase with increasing EAFS percentage as shown in Figs.5,6 and 7 due to EAFS contain high percentage of $\mathrm{CaO}$. 


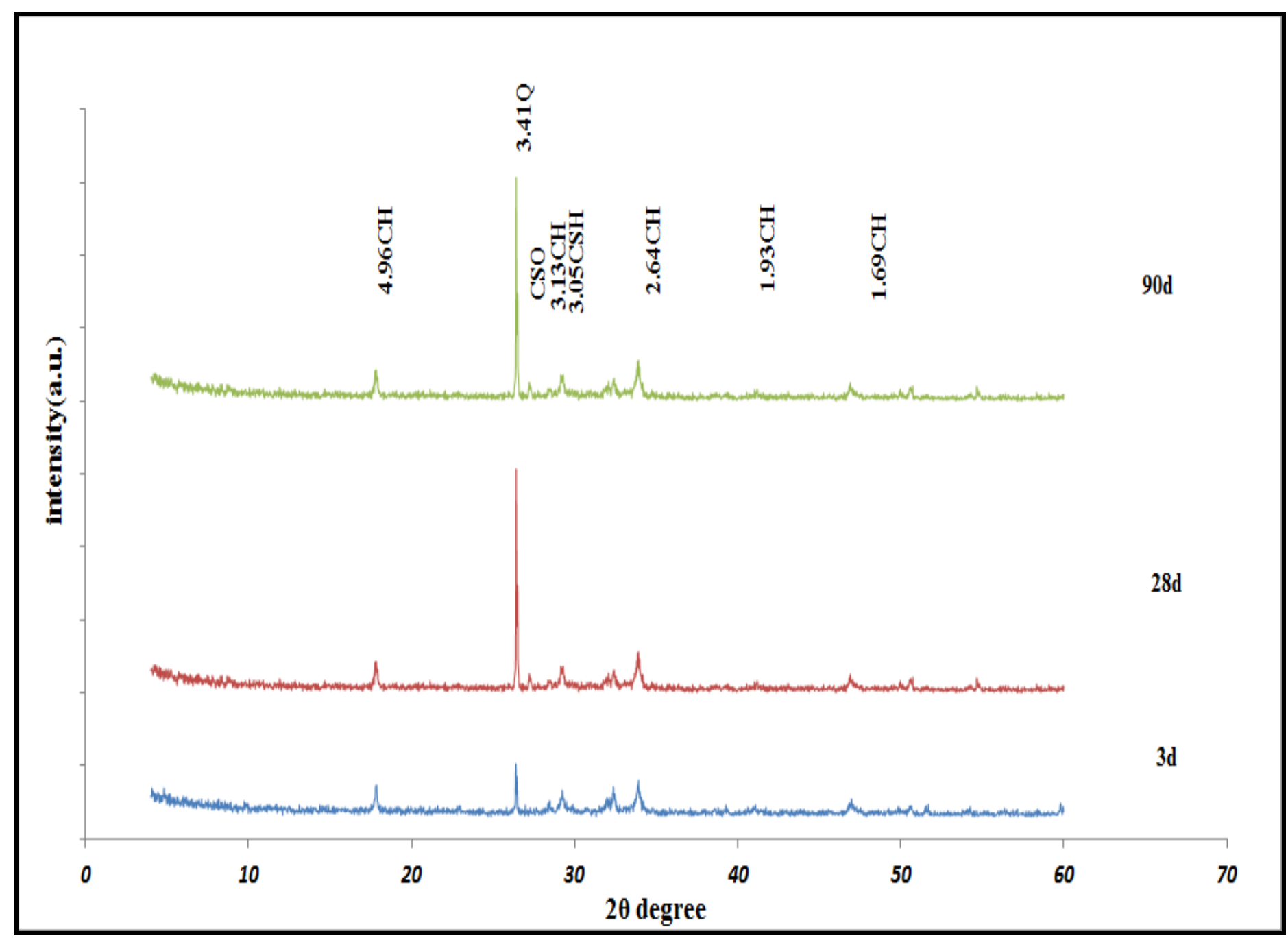

Fig.5 X-ray diffraction patterns for the mix( OPC+10\%EAFS) (CA1) 


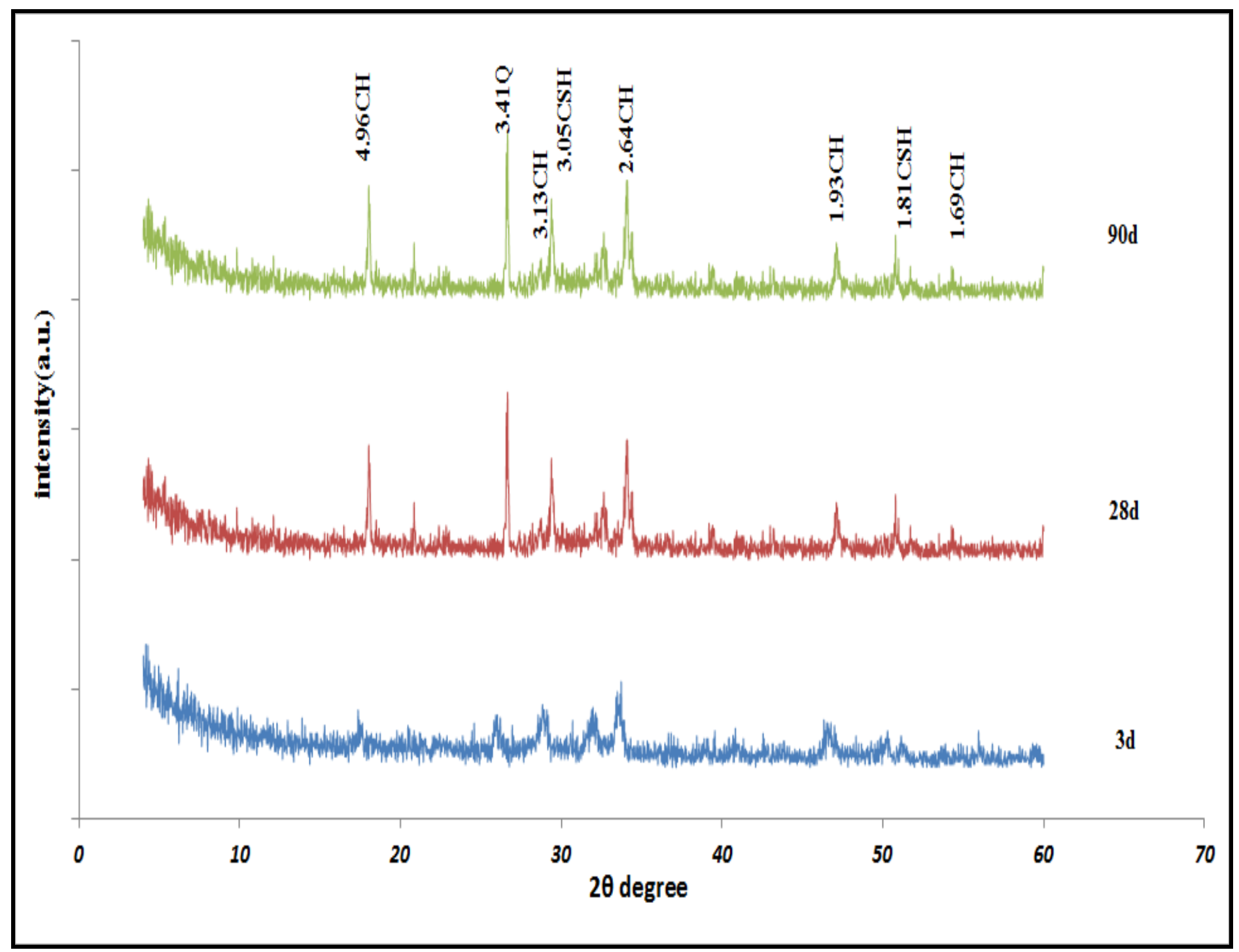

Fig.6 X-ray diffraction patterns for the mix OPC+20\%EAFS) (CA2) 


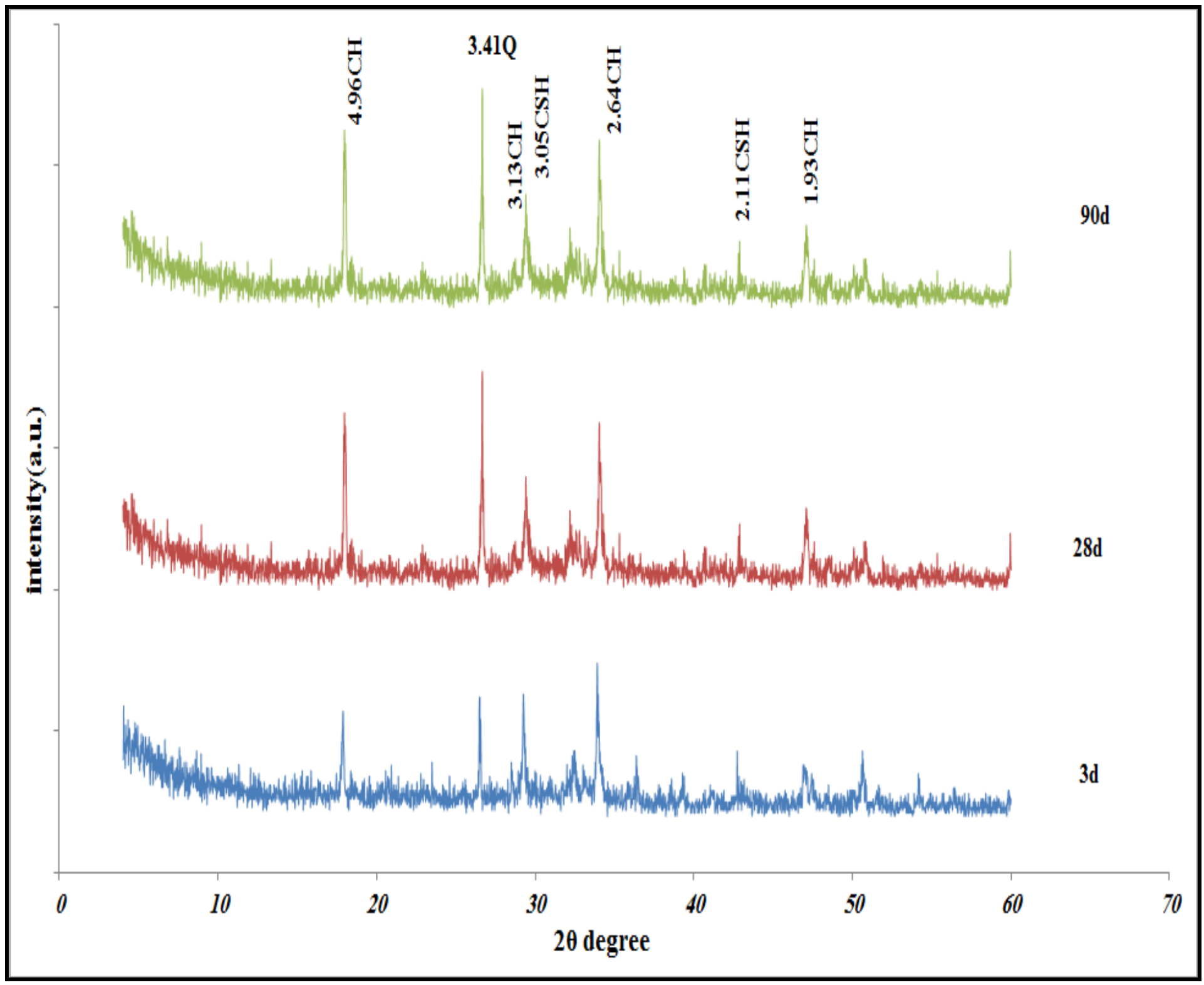

Fig.7 X-ray diffraction patterns for the mix (OPC+30\%EAFS) (CA3) 


\section{Conclusion}

The following conclusion that can be derived from this study is that:

The optimum replacement of OPC by EAFS that causes an increase in the compressive strength compared to neat OPC is $10 \%$ and $20 \%$ because EAFS contains aluminates and silicates that combine with the calcium liberated from the cement hydration and forming CASH gel binder .

\section{References}

[1] Amin M.S., S.M.A. El-Gamal, S.A. Abo-El-Enein, F.I. El-Hosiny ,M. Ramadan " Physico-chemical characteristics of blended cement pastes containing electric arc furnace slag with and without silica fume" ,HBRC journal: (2014) 1-7.

[2] Chen, L. , Lin, D-F.," Stabilization treatment of soft subgrade soil by sewage sludge ash and cement", Journal of Hazardous Materials, Volume 162: (2009) 321-327.

[3] Dermatas, D. Meng, X." Utilization of fly ash for stabilization/solidification of heavy metal contaminated soils", Engineering Geology, Volume 70: (2003) 377-394.

[4] Guney Y., Sari D., Cetin M. , Tuncan M.," Impact of cyclic wetting-drying on swelling behavior of lime-stabilized soil", Building and Environment, Volume 42:(2007) 681-688.

[5] Kangiwa1, I. A., U. A. Birnin-Yauri2 , Lubabatu M. Jodi3.2015 the 29th International Conference of Nigerian Meteorological Society (NMetS),Environmental and Health consequences of cement production $\mathrm{p} 4$.

[6] Karim MR, Zain MFM and Jamil M and Lai FC. 2011 International conference on biotechnology and environment management IPCBEE, Significance of waste materials in sustainable concrete and sustainable development $\mathrm{p} 7$.

[7] Nalbantoglu Z., "Effectiveness of Class C fly ash as an expansive soil stabilizer", Construction and Building Materials, Volume 18: (2004) 377-381.

[8] Yong, R. N. and Ouhadi, V.R.," Experimental study on instability of bases on natural and lime/cement-stabilized clayey soils", Applied Clay Science, Volume 35: (2007) 238-249. 


\section{استخدام خبث الفرن الكهربى لإنتاج أسمنت مخلوط \\ أسماء سرحان 1-سامية حامد 1'عصام كيشار 2 \\ 1 المركز القومى لدراسات السلامة والصحة المهنية،القاهرة. \\ 2 قسم الكيمياء، كلية البنات- جامعة عين شمس ،القاهرة.}

تم استخدام البوزو لانا الصناعية مثل حبيبات خبث فرن القوس الكهربائى. لتحضير اكثر من خليط بنسب مختلفة من تلك المادة بخلطها مع الاسمنت البورتلاندى العادى و المـاء ،تم در اسـة خو اص كل خليط بعد عملية التأدرت في الماء بعد

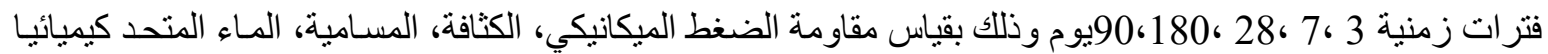
ودر اسـة التركيب الدقيق بإستخدام حيود الاشعة السينية ، من هذه الدراسـة نستنتج ان الخلبط المحتوي علي (أسمنت بورتلاندى 90\% +خبث فرن القوس الكهربائى10 \%) و (أسمنت بورتلاندى 80\% +خبث فرن القوس الكهربائى20 \%) انسب خليطان من حيث جميع الخصائص ويمكن استخدامه كبديل للاسمنت البورتلاندي العادي. 